\title{
The Interactive Impact Between Empowerment and Women Empowerment Programs in Selected Local Government Areas in Ekiti State
}

\author{
Makinde, Christiana Omone Bose ${ }^{1 *}$, Arogundade Toluwanimi Oreoluwa ${ }^{2}$, Adeoye, Ayodele ${ }^{3}$ \\ Ilesanmi Itunnu ${ }^{4}$, Banjo oluwafikayomi ${ }^{5}$ \\ ${ }^{1,2,5}$ Department of Social Work and Human Services, Babcock University, Ilishan-Remo, \\ Ogun State \\ ${ }^{3}$ Department of Education, Babcock University, Ilishan-Remo, Ogun State \\ ${ }^{4}$ University of Central Florida, 12494 University Blvd, Orlando, Florida 32816
}

\begin{abstract}
The Nigerian Society is purely Patriarchy in Nature, and since this patriarchal nature is evident in traditionally social, cultural, economic, and religious realms or settings, there is a need for Women's Empowerment that directly influences these sectors. This Study assessed Women's Empowerment programs in Ekiti State, Nigeria. A descriptive Survey design was adopted. Sample size of 500 respondents were selected from 10 local government areas in the State. The Analysis was conducted using Statistical package for social science (SPSS) version 23. The set null hypotheses were tested at a 0.05 level of significance. The set null hypotheses for Psychological Empowerment $(B=0.399, t=$ 22.853; $P<0.05)$, Social Empowerment $(B=0.318, t=15.160, P<0.05)$, Economic Empowerment $(B$ $=0.305, t=11.955 P<0.05)$ and Political Empowerment $(B=0.732, t=21.221, P<0.05)$. The findings revealed that Social, Economical, Political, and psychological empowerment has significant contributions to Women's Empowerment programs in Ekiti State. The study recommended that Social Empowerment, Economic Empowerment, Psychological Empowerment, and Political Empowerment are key contributors to Women's Empowerment.
\end{abstract}

Keywords: Empowerment, Political empowerment, Social Empowerment, Women Empowerment.

\section{Introduction}

A study opined that women empowerment is the process by which unequal power relations between men and women become distorted and women increase better parity with men: In other words, it is the procedure to challenge social limitations and social customs for women, which are barriers in the way of their progress so that their self-confidence level can increase and they can also contribute to nation's development and contribute in political, social and economic life at the local, regional and national level [1]. By women empowerment, we mean a more unbiased social position for women in society.
Women empowerment is one of the intensely discussed matters in the political and social ground. Social scientists have made a move on this matter in recent periods [2]. Empowerment is defined as the essential motivational process of an individual's knowledge of feeling empowered [3]. Empowerment is related to assigning authority to exercise personal discretion on one's own behavior at the place of work. There is an agreed view that empowerment is a process rather than a purpose $[4,5]$.

A study showcased that; women empowerment is a new expression in the language of gender literature [6]. The expression is used in two comprehensive 
senses, the general and specific in a general sense. It denotes empowering women to be selfdependent by providing them access to all liberty and opportunities, which they were deprived of in the past because of their being 'female' in the precise sense, women empowerment means enhancing their status in the power structure of the society.

In a related development, it is observed that Women's empowerment rests on certain factors linked to domestic management and social elevate [7]. As it helps to decrease poverty, millennium development goals can be understood. Most probably, women utilize their income on the physical health of the family, dietetic needs of domestic and education of children. Women's empowerment certainly effects on children and family better-off in the provision of food, expenses, and wellbeing. Also, Women's empowerment means women's ability to take part as equal partners in the social, economic, cultural, and political systems of a nation. Although, the world economy has advanced into the worldwide economy, in both industrialized and emerging nations women have been blocked from all walks of life for generations [8].

Like many countries, Nigeria maintains a national democratic constitution, boasting inclusive and equitable access to political participation. It was expected that facilitating Nigerian women's admission to one-third of positions in governing bodies would enable women to reach a critical threshold in the pursuit of changes in gender equity and, thus, women's empowerment [9]. However, the under-representation of Nigerian women in politics is both descriptive (that is, the number of women in political institutions is not reflective of the number of women in society) and substantive (that is, the unique perspectives of women are being heard in political institutions to ensure that women's needs, demands, and interests are incorporated into political agendas) [10].
When the reservation system was implemented, political parties were not necessarily inclined to support female candidates and the chances of being elected while not being a party member, or related to one, were slim. Moreover, the gap between constitutionally-instituted rights and the conditions which enable women to recognize and embrace those rights often remains fragmented by the absence of politicallyreinforced responses to women's daily needs and interest. Nigerian women's underrepresentation in the public and social domain, against their male counterparts and the inability to properly fit into the political arena has affected Nigerian women's empowerment and social status [11]. Without a more substantive conceptualization of female-male relations, both inside and outside of the public domain, filling quota prescriptions risks contributing to routes of women's empowerment with outcomes observed [11] wherein is seen as the emergence of a new social underclass.

Similarly, [12, 13, 14] document strategies for Nigerian women's empowerment which have necessitated the erasure of "femininity" within politics, the persistence of proxy-ruling and populist elections, and the regard for female leaders as goddesses imbued with a particular religious authority or vision. Moreover, the application of a gender lens to world politics reveals that today, when women do occupy political offices, they are often assigned to ministries dealing with the perceived "soft" issues of politics such as health and education, both of which are often shrouded under the "hard" political areas of defense, finance, and international trade, all of which are currently dominated by men [15].

The masculinization of certain domains in politics is frequently blamed for the marginalization of issues (such as comprehensive health care and education) which, when absent, are most apt to present women with destabilizing life condition [10]. 
While the strength and determination of Nigerian women's movements remain strong, the devolution of substantial political leverage is a complex and long process [16], for instance, the Aba women riot in 1929 portrayed the strength of Nigerian women in claiming their rights.

Women do not often see themselves as viable instruments of political participation and national development [17]. The level of women's participation in politics is still very low in Nigeria. Very few women in Nigeria contest for an elective post, rather, they limit their political activities to voting or appointment into political positions. The complacency of women in several aspects of national life not only reduces their capacity for manoeuver in a male-dominated society but also helps in perpetuating the culture of reducing women to positions and roles of second fiddle. This was why [18] believed that women see politics as a dirty game, a business that involves intimidation, rigging, assassination, the kidnapping of opponents and all sorts of electoral violence which they cannot cope with. This attitude of women may be related to their level of education and poor economic base a situation that hinders them from contributing meaningfully to national development.

\section{Economic Empowerment}

Women's economic empowerment can make the process of development more inclusive through a number of channels. For example, improving educational attainment for women and girls can strengthen the ability of household members to engage in productive activities and improve the efficacy of the labor force, thereby bolstering the economy's growth potential. Yet at the same time, structural changes that accompany the development process - as a result of technological change, international competition, or policy liberalization - can substantially alter the constraints that women face as they encounter new economic opportunities. The extent to which these forces lead to greater gender equality or inequality influences the inclusiveness of future growth [19]. A growing body of evidence indicates that an effective policy intervention in promoting self-employment is improving women's access to capital through loans and grants, often mediated via microfinance initiatives, rural banking reforms, and cash transfer programs. Such initiatives target individuals who have difficulty obtaining conventional loans through commercial banks. Women, in particular, have faced such difficulties due to their lack of collateral, a problem that is exacerbated by weak or nonexistent property rights for women in many developing countries. Without access to formal loans, low-income individuals have often had to rely on informal sector money lenders and other expensive sources of credit. By offering an array of pecuniary resources and financial services to the poor, both microfinance and rural banks have helped to extend credit in a number of countries with a variety of impacts [20].

Another means of improving women's access to financial capital is reforms that expand the reach of commercial banks to locations with thin or nonexistent financial markets. Despite the appeal of microfinance and other programs providing women with greater access to financial capital and cash, not all studies have been able to identify impacts on measures of women's entrepreneurship and empowerment, where the latter is usually considered to mean strengthened voice and agency for women in making decisions on matters that impact them.

Women's labor force participation rates in agriculture have risen in recent decades and agricultural export markets in developing countries have seen a feminization of foreign exchange earnings [21]. For example, women's participation has increased in high-value agricultural export markets, such as those producing cut flowers, fruits, and vegetables. Their production work in these sectors has been 
an important source of foreign exchange earnings for developing countries such as Kenya [22]. Yet the division of labor in the agricultural sector remains highly segmented along gender lines within and across the market and non-market economies. Salient features of this gendered division of labor are women's relatively greater burdens of unpaid housework and caring labor; agricultural productivity gaps that arise not from lower female efficiency but from inequitable access to land and to agricultural inputs; and market economies characterized by relatively lower proportions of women in high-paying full-time jobs. These inefficiencies have negative repercussions for agricultural output and sustained economic progress [23].

Hence the following hypotheses were raised:

1. There is no significant contribution of Social Empowerment, Political Empowerment, Psychological Empowerment and Economic Empowerment on Women Empowerment.

2. There is no significant individual contribution of Social Empowerment, Political Empowerment, Psychological Empowerment and Economic Empowerment to Women Empowerment.

3. There is no significant difference between Economic Empowerment and Women Empowerment.

\section{Methodology}

\section{Research Design}

In order to satisfy the objectives of this research, a quantitative research was held. This is a descriptive survey research.

\section{Population of the Study}

The target population for this research are women seeking women empowerment in social welfare unit, Ministry of women Affairs Ekiti State. In this Study, the population comprises of clients attended to at the social welfare unit, Ministry of Women Affairs, Ado Ekiti in 8 local government areas in the State.

\section{Study Area}

The Study Area for this study is the social welfare unit, Ministry of Women Affairs, Ado Ekiti, Ekiti State. The Women Empowerment programs in Ekiti State takes the shape of skill acquisition training, workshops, outreaches and creation of social support groups for Women. The clients under the women empowerment programs are able to assess sewing machines, grinding machines and sometimes loans in order to become independent and attain sustainability. Ekiti State has 16 local government areas. Empowerment programs are carried out in each of these local government areas. Some local government areas can be described as Urban or Semi-Urban while others are seen as Rural Communities.

\section{Sampling Size and Sampling Technique}

The Sample of the population of this study stood at 500 clients under the Women Empowerment program. A stratified sampling procedure was used in this study, the local governments in Ekiti state were divided into Urban and Rural Local government area after which a simple random sampling technique was used to select Four of each. Questionnaires were administered to respondents in 10 local government areas in the State. The Urban Local governments selected are Ado Ekiti, Ikere Ekiti, Efo Ekiti, Ekiti East and Ikole Ekiti. The Rural Local Governments are Ise/Orun, Emure, Ekiti South West, Ilejemeje and Moba Ekiti. A Total of 50 respondents were chosen at these local governments, bringing it to a total of 500 respondents.

\section{Research Instrument}

The Researcher designed a questionnaire as the data collection instrument for this study. The Questionnaire titled "Assessment of the Women Empowerment program in Ekiti State" was used in the study, the Questionnaire has 5 sections, Section 'A' is on Sociodemographic of the Respondents, Section ' $B$ ' is on the Relationship with Family members, Section 'C' 
is on Social Independence and Support, Section ' $\mathrm{D}$ ' is on Economic and Political Stability and Section ' $E$ ' is on psychological well-being.

The instrument was structured on a 4-point scale ranging from strongly agree, agree, disagree and strongly disagree. Respondents were given the questionnaire after their intervention and were asked to respond in degree of their agreement to each phrase.

\section{Validity and Reliability of Research Instrument}

Validity of an instrument is the degree to which it actually measures the variable used in the study. The instrument was validated by the project supervisor and other experts in the department, corrections were made and recommendations were taken into account before the questionnaire was administered. To ensure reliability, 16 copies of the instrument was pretested on respondents who were beneficiaries of a similar Women Empowerment program in Ibadan, Oyo State. The Result reflected that the questionnaire was reliable, it was ascertained with a score of 0.779 using a Crobach alpha method.

\section{Method of Data Collection}

After all modifications, the questionnaires were administered directly to the chosen sample. 500 copies of the questionnaire were successfully completed and returned. This activity was made possible with dedication on my part and with help from social welfare officers. For a sample to be truly a representative of the population, it must be as diverse as the population itself and sensitive to possible problems that could occur and as such, the questionnaires administered in this study was interpreted in Yoruba Language and few times the questions were read out to non-literate respondents. Therefore, the respondents included English-Speaking and Yoruba speaking respondents, representing the educated and non-educated members of the population.

\section{Ethical Consideration}

Ethical Approval was gotten from Ministry of Women Affairs, Ekiti State. In the study ethics was handled by the researcher by keeping the answers acquired strictly confidential. Besides, a prior permission was taken by the researcher from the target respondents before conducting the research. Next to this, the researcher tried to create and hold a climate of peace.

\section{Data Analysis}

The classification of raw data was essential for analysis and interpretation. The data was analyzed using Multiple Regression and Oneway Anova.

\section{Results}

$\mathrm{HO}_{1}$ : There is no significant contribution of Social Empowerment, Political Empowerment, Psychological Empowerment and Economic Empowerment on Women Empowerment.

$$
\begin{aligned}
& R=0.923 \\
& R^{2}=0.851 \\
& R=0.850
\end{aligned}
$$

Estimate: 3.14689

Table 1. Multiple Regression of Social Empowerment, Psychological Empowerment, Political Empowerment and Economic Empowerment on Women Empowerment

\begin{tabular}{|l|l|l|l|l|l|}
\hline Model & Sum of Square & DF & Mean Square & F & Sig \\
\hline Regression & 22038.218 & 3 & 7346.073 & 741.801 & .000 \\
\hline Residual & 3852.245 & 389 & 9.903 & & \\
\hline Total & 25890.463 & 392 & & & \\
\hline
\end{tabular}

a. Dependent Variable: Women Empowerment

b. Predictors: (Constant), Economic Empowerment, Social Empowerment, Psychological Empowerment. 
The above Table 1 indicate the multiple regression analysis of assessment of Women Empowerment Programmes in Ekiti State. The Result reveal that $\mathrm{R}^{2}=0.851$ and $\mathrm{R}=0.850$., That $85 \%$ of the Social Empowerment, Psychological Empowerment, Economic Empowerment are responsible for variance in Women Empowerment. Also, the df ${ }_{3,3389}$ is
741.807 at 0.05 level of significant, this is highly significant. Hence, the Hypothesis is of no significance, contribution is hereby discarded.

$\mathbf{H O}_{2}$ - There is no significant individual contribution of Social Empowerment, Economic Empowerment, Psychological Empowerment on Women Empowerment.

Table 2. Showing Individual Contribution of Social Empowerment, Psychological Empowerment, Political Empowerment, Economic Empowerment on Women Empowerment

\begin{tabular}{|l|l|l|l|l|l|}
\hline \multirow{2}{*}{ Model } & \multicolumn{2}{|l|}{$\begin{array}{l}\text { Unstandardized } \\
\text { Coefficients }\end{array}$} & $\begin{array}{l}\text { Standardized } \\
\text { Coefficients }\end{array}$ & t & Sig. \\
\cline { 2 - 6 } & $\mathbf{B}$ & Std. Error & Beta & & \\
\hline (constant) & 7.122 & .855 & & 8.325 & .000 \\
\hline Social Empowerment & 0.782 & .052 & .318 & 15.160 & .000 \\
\hline Psychological Empowerment & 1.661 & .073 & .399 & 22.853 & .000 \\
\hline Economic Empowerment & 1.158 & .097 & .305 & 11.955 & .000 \\
\hline Political Empowerment & 1.569 & .074 & .732 & 21.221 & .000 \\
\hline
\end{tabular}

A. Dependent Variable: Women Empowerment

The above Table 2 reveals the individual contribution to Women Empowerment. It shows that Political Empowerment contributes most with $\mathrm{B}=0.732, \mathrm{t}=21.221, \mathrm{P}<0.05$ followed by Psychological Empowerment with $\mathrm{B}=0.399, \mathrm{t}=22.853 ; \mathrm{P}<0.05$, followed by Social Empowerment with $\mathrm{B}=0.318, \mathrm{t}=$ 15.160, $\mathrm{P}<0.05$ and Economic Empowerment with $\mathrm{B}=0.305, \mathrm{t}={ }^{`} 11.955 \mathrm{P}<0.05$. All are significant. Hypothesis of no significant contribution is hereby discarded and the alternate hypothesis is hereby accepted.

$\mathbf{H O}_{3}$ : There is no significant difference between Economic Empowerment and Women Empowerment.

Table 3. One Way Analysis of Economic Empowerment and Women Empowerment

\begin{tabular}{|l|l|l|l|l|l|}
\hline & Sum of Square & Df & Mean Square & f & sig \\
\hline Between groups & 23347.982 & 10 & 2334.798 & 134.403 & .000 \\
\hline Within Groups & 6774.911 & 390 & 17.372 & & \\
\hline Total & 30122.893 & 400 & & & \\
\hline
\end{tabular}

The Table 3 reveals the one-way Anova of Economic Empowerment \& Women Empowerment. The results reveal that $\left(\mathrm{df}_{10,390}\right.$, $\mathrm{F}=134.403, \mathrm{P}>0.05)$ is significant. Hence, the hypotheses of no significant difference are hereby discarded and the alternate accepted. Hence, there is significant difference.

\section{Discussion}

In hypothesis one, it was found that there is a significant contribution of Social
Empowerment, Political Empowerment, Psychological empowerment and Economic Empowerment to Ekiti State Women Empowerment programs. This finding is supported by [22, 23] that processes of empowerment occur in concrete political, economic and social settings. This is because girls face violence, domination and the exercise of other sorts of discriminatory power from these sectors. 
In Hypothesis two, it was discovered that there is significant individual contribution of Economic Empowerment, Political Empowerment, Psychological Empowerment and Social Empowerment to Women Empowerment. This finding is supported by [22] who said there are numerous pathways to women empowerment however essential conditions consists of women collective motion, constitutional and criminal reform, social and monetary coverage measures, and modifications in sociocultural norms. All these are strategies of Social, Political, and Economic empowerment and it implies that every one of them have a significant individual contribution to women empowerment.

In Hypothesis three, it was found that there is significant difference between Economic Empowerment and Women Empowerment. This Finding was supported by [23] who talked about the importance of giving Women the opportunity to earn an income but also how useless it is if women are not equipped to make decisions regarding their education (Political Empowerment) and equipped with the confidence to exercise agency (Psychological empowerment). This implies that Economic Empowerment is not the only dimension of Women Empowerment and is therefore not Women Empowerment.

\section{Conclusion}

As a result of the findings, it is concluded that the Social Empowerment, Economic Empowerment, Psychological Empowerment

\section{References}

[1] Renu J., and Renu, D. (2015). Corporate social responsibility and the empowerment of women: An Indian perspective. Social Responsibility Journal. 3(4):40-48. https://www.iosrjournals.org/ Corsun DL, Enz CA. Predicting Psychological Empowerment Among Service Workers: The Effect of Support-Based Relationships. Human Relations. 52(2),205-224. https://journals.sagepub.com/. and Political Empowerment are key contributors to Women Empowerment.

\section{Recommendations}

Based on the findings, the following recommendations were made

1. Women Empowerment programs needs to be structured using women own experiences, rather than relying solely on already existing theories or practices.

2. Efforts to bring out Women Empowerment must also focus on eliminating societal constructs and constraints that leads to discrimination, prejudice and inequality.

3. Sexuality is an important but often overlooked dimension of women empowerment. Positive strategies in sexuality such as education on reproductive rights could be the missing puzzle in bringing about change in the lives of women.

\section{Acknowledgement}

This paper and the exploration behind it would not have been conceivable without the Federal Ministry of Women Affairs Ekiti, and the local government areas cooperation by allowing access to participants, thereby getting information. Balm in Gilead for Sustainable Development, an NGO also aided access to information.

\section{Conflict of Interest Statement}

The authors declare that there is no conflict of interest.

[2] Akhter R, and Ward KB. (2019). Globalization and gender equality: A critical analysis of women's empowerment in the Global Economy. 13:141-73.

[3] Kabeer N. (2015). Gender equality and women's empowerment: A critical analysis of the Third Millennium Development Goal 1., Gender \& Development, 13(1):13-24.

https://www.tandfonline.com. 
[4] Dasarathi, B. (2016). Empowerment of Indian Women a Challenges for 21st century. In Women Empowerment Principle. 18 (2), 1 - 4.

[5] Mayoux L, Hartl M. (2019) Microfinance and women's empowerment: Virtuous spirals. Gender and Rural Microfinance: Reaching and Empowering Women. International Fund for Agricultural Development (IFAD).

[6] Mohak, R. (2014). Schemes and Strategies for Women Empowerment in India. 2014;1- 12.

[7] UNIFEM (2013). Progress of the World Report. Retrieved April 2015 from http://portal.unesco.org/en/ev.phpURL_ID $=13081 \&$ URL_DO=DO_TOPIC\&URL_SECION=201.html.

[8] Tremblay, M., and Pelletier, R. (2015). More Feminists or More Women? Descriptive and Substantive Representations of Women in the 2014 Canadian Federal Elections. International Political Science Review, (21)4, 381-405.

[9] Nussbaum, M. (2014). Sex, laws and inequality: What India can teach the United States. Daedalus, 131(1), 95-106.

[10]Lama, S. T. (2001). The Hindu goddess and women's political representation in South Asia: Symbolic resource or feminine mystique. International Review of Sociology, 11(1), 5-20.

[11] Banerjee, S. (2013). Gender and Nationalism: The masculinzation of hinduism and female political participation in India. Women's Studies International Forum, 26(2), 167-179.

[12] Bird, K. (2013). The Effects of Gender Parity in Elections: The French Case. In: Gaffney J. (ed.), The French Presidential and Legislative Elections of 2014. Aldershot, UK: Ashgate. empowerment, and rights(pp.128-138). Boston, Massachusetts: Harvard University Press.

[13]Peterson, S., and Runyan, A. (2015). Global Gender Issues: Dilemmas in World Politics. Boulder Westview Press.

[14] Chaudhuri, S., and Heller, P. (2012). The plasticity of participation: evidence from a participatory governance experiment. Paper presented at the Workshop on "Measuring Empowerment: Cross Disciplinary Perspectives" held at the World Bank in Washington, DC on
February 4th and 5th. Retrieved in April 2015 from http://poverty2.forumone.com/library/view/13892/. [15] Okemakinde, T. (2014). Women Education: Implications for National Development in Nigeria. European Journal of Globalization and Development Research. 9 (1) 553-564.

[16] Agu, S. (2014). Gender Equality, Education and Women Empowerment: The Nigerian Challenge. Multidisciplinary Journal of Research Development, 8; $1: 66-72$.

[17]Rodgers, Y. M. (2017). Women's Empowerment in the Labor Market: Why Is it Smart Economics? Rutgers University, Nidhiya Menon, Brandeis University.

[18]Banerjee, A., Dean, K., and Zinman, J. (2015). "Six Randomized Evaluations of Microcredit: Introduction and Further Steps," American Economic Journal: Applied Economics 7(1): 1-21.

[19] Lastarria-Cornhiel, S. (2006). "Feminization of Agriculture: Trends and Driving Forces," Background Paper for the World Development Report, 2008. Washington DC: World Bank.

[20]Food and Agriculture Organization, International Fund for Agricultural Development, and International Labour Organization (FAO/IFAD/ILO). 2010. Gender Dimensions of Agricultural and Rural Employment: Differentiated Pathways Out of Poverty: Status, Trends, and Gaps. Rome: FAO.

[21]Food and Agriculture Organization (FAO). 2016. Gender and Land Rights Database. Rome: FAO.

[22] Hossain, N. (2012) 'Security and the Pathways of Women's Empowerment: Finding from a Thematic Synthesis of the Pathways of Women's Empowerment Research'. IDS Working Paper No. 406. Sussex: Institute of Development Studies.

[23] Kabeer, N. (2011) 'Between Affiliation and Autonomy: Navigating Pathways of Women's Empowerment and Gender Justice in Rural Bangladesh', Development and Change 42.2: 499528. 